\title{
The Ecosystem for Online Entrepreneurship Teaching
}

\author{
Natalya F. Altukhova ${ }^{1}$, Elena V. Vasilieva ${ }^{2}$ \\ Department of Business Informatics \\ Financial University under the Government of the Russian Federation \\ Moscow, Russia \\ ${ }^{1}$ nfaltuhova@fa.ru, ${ }^{2}$ evvasileva@fa.ru
}

\begin{abstract}
The authors voice the problems of teaching students technological entrepreneurship. The authors also highlight the basic requirements for the competencies of the head, that today must have knowledge in the professional and technical field, be able to think globally and have a wide managerial outlook and experience to have the gift of foresight and work ahead of the curve, translating the strategy of the organization into a new quality. The key participants in the process of training specialists whose competencies can be in demand in the digital world are identified. Recommendations for improving the effectiveness of the learning process are given. An important advantage of the approach to teaching the course "Internet entrepreneurship" is the integration of Lean Startup methodology and Design thinking. The authors developed cases and practical recommendations for the creation of digital services based on the Human-Centered Design.
\end{abstract}

Key words: IT education, personnel training, technological entrepreneurship, digital markets, design thinking.

\section{INTRODUCTION}

Digitalization of the economy and society will revolutionize the work of organizations and will force managers to reconsider the strategy of their functioning, because new ways of management, approaches to recruitment will be needed. In addition, it is important for managers themselves to strengthen and improve their competence not only in their subject areas but also in the management of work and people in order to achieve success. The speakers of the digital conferences usually highlight the importance of team skills development and personal development of a person throughout his life. Soft skills are necessary for large companies, who find it most difficult to adapt the control mechanisms and technological platform to the requirements of the digital future. The labor market today is in demand for ambition and entrepreneurship.

\section{THE DIGITAL MENTALITY OF THE HEAD AND STAFF OF THE STATE ORGANIZATION}

The company introduced the position of Director of digital technology, because they understand the importance of management of digital processes and digital transformation activity. At present, the issues of updating the structure of the organization in state corporations and organizations are being discussed. There are recommendations to introduce in large state corporations and structures responsible for the implementation of the program "Digital economy of the Russian Federation", the position of Director or Top Manager for digital transformation, Chief Digital Officer (CDO) or Head of digital transformation. The duties of the Director of digital technologies include the strategic development of the organization in the context of its transition to digital platforms, the transfer of its activities in the Internet space.

The Ministry of economic development of the Russian Federation, together with Rosatom, Rostech, digital economy, the center for strategic development, the Agency for strategic initiatives (ASI), Russian Railways, MTS and other representatives of scientific communities and business structures, developed and published on the website the documents "Plan for the formation of state corporations and companies with state participation of structural units for digital transformation and the organization of their work for 20182019".

The tasks of the top Manager for digital transformation will include the introduction of "end-to-end" technologies provided by the program "Digital economy", including the collection, processing and analysis of big data (Big Data), neural networks, blockchain, artificial intelligence (AI), robotics and sensor technology, simulation system of the full life cycle of the product, the Internet of Things (IoT), augmented and virtual reality (AR/VR), quantum and cloud computing. Based on this list of tasks, we conclude that the head of the new formation, which will determine the digital strategy of the company and be responsible for its transition to a new quality, must have extensive knowledge in the technical field and business, be well versed in information and communication technologies (ICT), be able to think globally, be competent in finances, marketing, own sales tools, have a wide managerial horizons and experience, have the gift of foresight (proactivity) to be able to work ahead of the curve, and enterprise, "to be able to manage change and do it quickly".

As a digital leader, a Manager must have the skills of team building and management, interpersonal communication, be able to engage and motivate his subordinates to new tasks and self-improvement. A new type of manager should develop a culture of innovation in the organization. Important questions that the manager should ask himself today: "Do you have specialists for the introduction of new technologies? Are your employees ready for changes?" Employees must be ready for 
changes, it understand the essence of changes so that the digital transformation of their activities can be successfully implemented.

The lack of digital competence and the absence of positive expectations for the introduction of ICT led to the refusal to make a decision on the beginning of digital changes in the organization. The low digital literacy or lack of ICT experience of staff in organizations, as well as their possible neutral or negative attitude to changes related to digital technologies, are called "fear factors" of global corporate digital transformations [1].

But how to improve the effectiveness of training of future leaders of the digital world?

\section{THE ECOSYSTEM OF THE COURSE "INTERNET-ENTREPRENEURSHIP"}

In 2015, the Financial University under the Government of the Russian Federation signed an agreement with the Foundation for the development of Internet initiatives (IIDF) on the inclusion of the course "Internet entrepreneurship" in the educational programs of the bachelor's and master's degree in the field of "Business Informatics". Over the past two years, IIDF has been actively promoting the idea of introducing this course in more than 100 universities in Russia, as well as in Kazakhstan and Belarus.

However, we are faced with a problem that is likely to be relevant for many economic universities. Ideas offered by students in the classroom on the course "Internet entrepreneurship", and do not reach the stage of implementation in a real product, are not implemented in the Internet service or mobile application. Our students, who have good training in business engineering, management, are not confident enough in application development. As a result, for 2 years of teaching students the basics of Internet entrepreneurship, we have accumulated a sufficient base of unrealized useful ideas. This would not have happened if our university or other universities had a developed ecosystem of training support for Internet entrepreneurs.

Participants in such ecosystem (Fig. 1) should be not only teachers and students of one university, but also some support of the university management. The course itself and the new forms that we use in training and for which the IIDF highly appreciated us, giving twice the title of laureate, could not be realized without the participation of the Vice-Rector for educational and methodical work, the head of the educational program. Now we are promoting the idea of Internet entrepreneurship, organizing various sessions of design research, hackathons, business games within the framework of scientific conferences and events at the Financial University, as well as holding elective classes, including courses for teachers and administrative staff. Now the course "Internet entrepreneurship" has become mandatory in the direction of 38.04.05 "Business Informatics", master's program "Strategic Management of Information Technologies in Business".

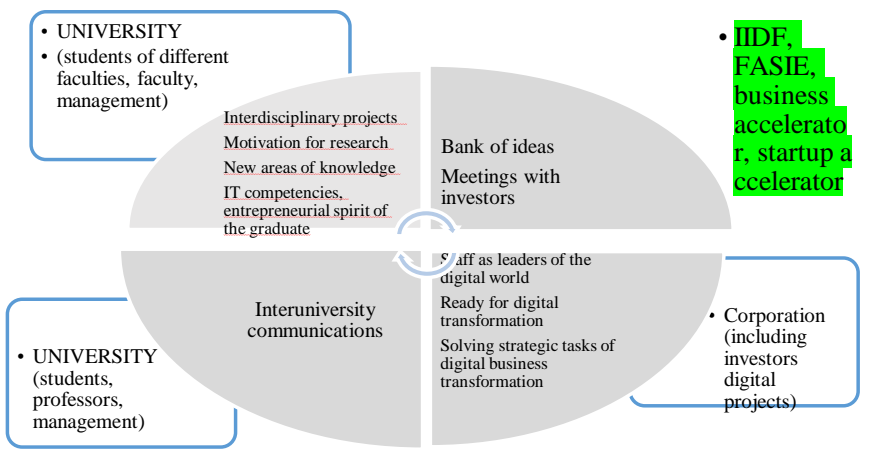

Fig. 1. The ecosystem of the course "Internet Entrepreneurship"

We also believe that it is important to develop interuniversity relations when students of different faculties or areas of training of different universities can be involved in the project, which will ensure the feasibility of the principle of an interdisciplinary approach to the project. Communication and organizational activities, as well as the interaction of the authors of the best projects with investors, can take on the IIDF, as the main inspirer of the course.

An important role is given to IT companies, which will receive not only interesting design solutions, but also their potential employees prepared to work in the digital markets. It is not for nothing, for example, the introduction of Design Thinking principles among key partners is one of the key areas of the SAP technology leader. For the development of new customer-centered services in the context of digitalization of society and the economy, it is important for advanced companies to be able to determine the deep needs of customers, so they use innovative techniques and tools. Design Thinking is now implemented in IBM, General Electric, Procter \& Gamble, Philips Electronics, Airbnb. In Russian, Design sessions are held in Sberbank, Raiffeisen bank. In the ecosystem of training of future leaders of the digital world also become important participants and entrant of it areas of universities. Career guidance work should be carried out with students to the profession came aimed at the result of people.

\section{THE APPROACH OF DESIGN THINKING IN THE ECOSYSTEM OF THE COURSE "INTERNET ENTREPRENEURSHIP”}

Note that an important advantage of our approach to the teaching of the course "Internet Business" is to integrate the Lean Startup methodology [2-4] with the stages of Design Thinking, according to "d.school", as follows: Empathize, Define (the problem), Ideate (Generation and Voice), Prototype, and Test. This allowed us to solve the problem arising in practice at many universities, testing this course in the educational process, with the formation of new ideas, customer research at the stage of customer development, testing hypotheses with the participation of representatives of the target audience. Graduates of schools who are passionate about information technology and decide to go to university to continue IT education are also becoming important participants in the ecosystem of training future leaders of the digital world. Therefore, we believe that universities should actively cooperate with schools so that schoolchildren come to the profession, who are focused on results. This approach should now become the basis for the production of goods and services. The importance of studying the value of any innovation for people before its implementation in the product is stated in the works of Blank [2], Kotler [5] and other scientists. Creating the soul of a brand requires knowledge 
not only of the laws of marketing and business, but also psychology, anthropology, cultural studies. And empathy, which is the basis of most Design Thinking techniques is, first of all, understanding the experience of the consumer, his feelings and feelings, which is aimed at further filling the developed innovative product understandable to the consumer emotions [6-8].

How to implement Design Thinking in the processes of the company that has chosen the strategy of digital transformation? The answer to this question depends on the purpose of the company. This can be a solution to the problems of studying changes in customer requests or problem areas in customer service, finding ways to transform outdated approaches in doing business, training staff tools to make decisions in unusual situations. Session duration is possible from 8 hours to 3 days. Tasks step-by-step can be performed in a team from 5 to 7 people.

During the two years of teaching the course "Internet Entrepreneurship," we have tested the inclusion of a variety of Design Thinking tools in the Lean Startup methodology. Work on projects of technological entrepreneurship was both team and individual. The team came up with the idea, tested hypotheses in customer research. The analysis of startup metrics and calculation of economic indicators of the project solution, description of business processes of startup activity and definition of ways of holding clients were carried out individually. The results were made not only in the presentation of the idea but also in the writing of research works in which it was necessary to show the features of its creation, to give proposals for promotion. The course "Internet Entrepreneurship" was held in the Financial University within the faculty classes (36 hours, every two weeks), training practice (two weeks, from 9.00 to 13.00 , four times a week). However, in our deep conviction, for the success of learning the skills to create a startup is suitable for a rich program, as it was in the organization of training practice $[8 ; 9]$ when nothing distracted from the project, when each day began with a warm-up thinking, learning new techniques of design thinking, adjustments and mentoring by teachers, teamwork and research.

We have seen the main purpose of the course is to give students an idea about the features of creating a startup, promotion, in practice, tried out all the steps from the development of innovative ideas to testing and promotion of the project solution feel like young entrepreneurs. For two years we have been actively implementing various forms of research, communication and design activities. As part of the faculty stage of the International student scientific conference, it has become a tradition for our students to participate in the hackathon, in which they study the principles of design thinking. Student teams develop business ideas, create prototypes of products or services that solve the problems of the city, society, etc.

Design thinking and the Lean Startup methodology, if included in the training course for IT specialists, develop students' qualities such as enterprise, teamwork, trust in success, not fear failure, which will help them solve difficult nonstandard situations in their future profession in the face of uncertainty. Our approbation in the educational process of new forms of education has given good results in final qualifying works. In their master's theses, our graduates included the results of design research and offered innovative digital development strategies for companies such as Russian Post, Sberbank. We believe that these are important steps to the transformation of the educational process. The skills of creative thinking, teamwork and personal development, which we are developing with such new methods of training our graduates will make them competitive in the labor market, will allow them to competently shape their strategies for professional growth.

\section{CONCLUSION}

The digital transformation of organizations is becoming a reality, the management of which requires the formation of new skills from the head. It is he who has a special role in the processes of digital transformation as the main carrier of possible technological changes, the competent implementation of which should provide quality, positive changes in the organization.

The trend of customer orientation and reactive, sometimes unexpected changes in their needs, tastes, preferences make business change, look for new business moments, which, in Gartner's terminology, means a constant search for short-term opportunities used dynamically: "...a business moment can come from nowhere, and yet they are becoming more and more" (Gartner Symposium/Itxpo 2013). Until recently, the human resource was perceived as the main participant of business processes in enterprises, as an integral part of the organizational capital of the company. However, automation and the introduction of industrial technologies 4.0 replace human programs, robots, bots, drones, etc. This does not mean that in the new era of human functions in the process will be minimized.

\section{REFERENCES}

[1] Алтухова Н.Ф. Условия реализации цифровой трансформации в организации // Экономика. Налоги. Право. 2018. Т. 2. С. 70-75. [Altuhova N.F. Conditions for the implementation of digital transformation in the organization" // Economics, Taxes \& Law. 2018 Vol. 2. P. 70-75]. DOI: 10.26794/1999-849X-2018-11-2-70-74.

[2] Blank S. The Four Steps to the Epiphany: Successful Strategies for Products that Win. Sussex: Quad/Graphics, 2014.

[3] Blank S., Dorf B. The Startup Owner's Manual: The Step-By-Step Guide for Building a Great Company. Pescadero K\&S Ranch Press, 2012.

[4] Ries E. The Lean Start-up: How Today’s Entrepreneurs Use Continuous Innovation to Create Radically Successful Businesses. NY: Crown Business, 2013.

[5] Kotler P., Kartajaya H., Setiawan I. Marketing 3.0: From Products to Customers to the Human Spirit. NY: John Wiley \& Sons, Inc., 2010.

[6] Kelley T., Kelley D. Creative Confidence Unleashing the Creative Potential Within Us All. New York: Barnes \& Noble, 2013.

[7] Liedtka J., Ogilvie T. Designing for Growth: A Design Thinking Toolkit for Managers. New York: Columbia University Press, 2011.

[8] Vasilieva E. Design thinking: a little bit about the approach and a lot about the tools of creative thinking, learning client requests and creating ideas: monograph. Moscow: RU-SCIENCE, 2018. (In Russ.)

[9] Алтухова Н.Ф., Васильева Е.В., Громова А.А. Опыт примене- ния техники дизайн-мышления в курсе «Интернет-предпринимательство» // CEUR Workshop Proceedings. 2016. Vol. 1761. P. 219-225 [Altuchova N., Vasilieva E., Gromova A. Teaching experience of Design Thinking in the course of "Internet-business" // A. Conference: CEUR Workshop Proceedings. 2016. Vol. 1761. P. 219-225]. 